International Journal of Social Science (IJSS)

Vol.1 Issue.5 February 2022, pp: 627-636

ISSN: 2798-3463 (Printed) | 2798-4079 (Online)

\title{
DESIGNING SYLLABUS OF ENGLISH FOR TOURISM (EFT) FOR THE ELEVENTH GRADE STUDENTS OF SMK NEGERI 1 PRAYA IN THE ACADEMIC YEAR OF 2020/2021
}

\author{
By \\ Endang Sri Wahyuni \\ Tourism Polytechnic of Lombok \\ Email: endang.wahyuni@ppl.ac.id
}

\begin{tabular}{l}
\hline Article Info \\
\hline Articlehistory:
\end{tabular}

Keywords:

Syllabus, English for Tourism, Needs Analysis.

\begin{abstract}
The study aims at designing a syllabus of English for Tourism based on the level and the needs of the eleventh grade students at SMKN 1 Praya. The syllabus was designed based syllabus in the Curriculum 2013 where it focused on scientific approach. To design satisfactory syllabus, the researcher did Research and Development $(R \& D)$ study by adopting five steps; (1) doing needs analysis (2) drafting syllabus (3) implementing the product, (4) revising the syllabus and (5) designing the final product. In term of research method, the researcher employed qualitative method in gathering the data. Four data collection instruments, a questionnaire, interview, study documentary and observation, were used to know the students' needs in the syllabus of English for tourism. The result of research was indicated that the most of respondents needed speaking skill in EFT course. Considering the findings, language functions and active learning were developed in the syllabus. There were two topics were developed namely topic of tourism object and local object. After drafting the syllabus, the researcher implemented the product at the restricted class and the whole class in five meetings. At the end of the implantation a feedback was administered, the result of which indicated that, the informants had positive opinion about the teaching and learning process by using the syllabus. To know the effectiveness of the syllabus, tests were given to students. From the results, they had significant progress from the first to the third test so that the syllabus was applicable to teach Mulok of English for Tourism for SMKN 1 Praya students.
\end{abstract}

Thisisan open accessarticleundertheCC BY-SAlicense.

CorrespondingAuthor:

Endang Sri Wahyuni

Tourism Polytechnic of Lombok

Email: endang.wahyuni@ppl.ac.id

\section{INTRODUCTION}

Language is the most important thing for people as a means of communication. The importance of language is essential to every aspect in our everyday lives. We use language to inform the people around us of what we feel, what we desire, and understand the world around us. Language is a valuable instrument of thought dealing with verbal and non-verbal interaction patterns. When people interact with others in society at anytime and anywhere certainly, they must use a language. Without a language, people will find some troubles when they do their activities toward the others. There is no society without a language. Brown (1998) points out language and society are intertwined that it is impossible to separate one from the other: Society cannot exist without language, and language cannot exist without society.

In this world, we have numerous languages, which are different from another. The role of language helps people to show their perspective concerning something in a multitude of situation. How somebody distinguishes idea broadly tends to his or her language proficiency. The language proficiency includes reading, listening, writing, and speaking. Therefore, it is important for an English teacher who has good English skills to give positive contribution to students in mastering the target language. 
In teaching and learning process, an English teacher has to teach students effectively. The use of all method of language teaching is important by teacher. It is regarded to no single method is the best in teaching a target language. The teacher has responsibility to design a good planning for classroom management. He or she needs to comprehend how to arrange the planning. With variety of the students' skill levels in every classroom, teachers must employ effective strategies that allow each student to learn the teaching material. To be effective teaching, a teacher must use a good method and strategy. The effective attitudes and actions employed by teachers in the classroom make a positive difference on the lives of their students because the learning of language depends on the way it is presented to the learner. In teaching, a teacher has many options when choosing a strategy to teach. By knowing the teaching strategy in the class, the teachers will be guided to know how to teach English effectively. Weimer (n.d) points out the best teachers do know their material, but they also know a lot about the process. They have at their disposal a repertoire of instructional methods, strategies, and approach a repertoire that continually grows, just as their content knowledge develops. They never underestimate the power of the process to determine the outcome. With this understanding, content is not a barrier to teacher development. Certainly the teachers cannot avoid many problems in teaching language skills because it is a foreign language. During the process of learning a foreign language there might be a number of problems both to teachers and learners. To teachers, the difficulties would be in form of techniques, strategies and methods, while to students, the difficulties might be in language interference and limited English vocabularies. Ortiz (2001) explains students with limited English may fail because they do not have access to effective bilingual or English as a second language (ESL) instruction. To solve the problems, it needs to design a good design for increasing the students' achievement in learning English. It can be about curriculum and syllabus. Both are essential in the implementation of teaching and learning process. A curriculum contains knowledge, skills, and attitude which provide an indication of the effective learning. The curriculum is broader than a syllabus because the syllabus just describes the content of a programmer and can be seen as one part of a curriculum. According to Kimm (2007:2) defines the word curriculum is derived from the Latin currere meaning 'to run'. This implies that one of the functions of a curriculum is to provide a design which enables learning to take place. Curricula usually define the learning that is expected to take place during a programmer of study in terms of knowledge, skills and attitudes, they should specify the main teaching, learning and assessment methods and provide an indication of the learning resources required to support the effective delivery of the course. Richards (2010) notes the term of curriculum refers to the overall plan or design for a course and how the content for a course is transformed into a blueprint for teaching and learning which enables the desired learning outcomes to be achieved. Nunan (1988:3) states that curriculum is concerned with making general statements about language learning, learning purpose, and experience, and the relationship between teachers and learners. It contains banks of learning items and suggestions about how these might be used in class. Baharuddin (2009:109) a curriculum is an attempt to communicate the essential principles and features of an educational proposal in such a form that is open to critical scrutiny and capable of effective translation into practice. Therefore, a curriculum is a learning program specifically designed and systematically arranged for the benefits of a group of students. It is given to the schools to achieve the goal of education. As a program design, a curriculum is the fundamental of the learning process where the success and the failure of learners depend on the understanding of curriculum being used. Watkins and Kritsonis (2008:4) states the necessity of having a curriculum foundation is helping students to achieve academically not only in school system but also in the future where it will contribute to society as fully educated, functioning, and productive adults. Here the set of program in the curriculum is expected to change the learners' behavior; to be confident, responsible, and creative. Therefore, the curriculum should able to describe the process of teaching and learning structurally.

Curriculum provides general statements about the rationale language learning and language teaching, objectives and targets learning purpose, and implementation of a program. The curriculum of English course attempts to develop the use of English on three major purposes; social interaction, academic achievement, and cultural enrichment. Hence in designing the curriculum, need to comprehend many aspects in teaching and learning process. It is because the curriculum is a process of thinking through how the teachers want to organize the students and should be what the teacher wants students to learn over years. Nation \& Macalister (2010:1) states

"Curriculum design can be seen as a kind of writing activity and as such it can usefully be studied as a process. The typical sub-processes of the writing process (gathering ideas, ordering ideas, ideas to text, reviewing, editing) can be applied to curriculum design, but it makes it easier to draw on current curriculum design theory and practice if a different set of parts is used."

David Nunan makes various observations about teachers who develop curriculums and point out that developing the curriculum requires time, skill, and support. He recognized that issues such as these are vital for teachers faced with the daunting task of developing curricula. Richard (1990) mentions a step in curriculum development of second language teaching comprises needs analysis, goal setting, syllabus design, and methodology and testing and evaluation. He also explained the curriculum development should focuses on determining what 
International Journal of Social Science (IJSS)

Vol.1 Issue.5 February 2022, pp: 627-636

ISSN: 2798-3463 (Printed) | 2798-4079 (Online)

DOI: https://doi.org/10.53625/ijss.v1i5.1305

knowledge, skills, and values students learns in schools, what experience should be provided to bring about intended learning outcomes, how teaching and learning in school or educational system can be planned, measured, and evaluated.

An English teacher should consider a curriculum as a thinking process of how the teachers want to organize the learners in the classroom. The teacher also need know about the important of syllabus in teaching and learning process because the syllabus can facilitate the teaching and learning of language and contribute to the learners' achievement of communicative competence because it provides a blueprint for teachers and examiners to follow. Some syllabuses focus on specifications of content (product syllabuses); others include guidance on teaching and learning as well as content (process syllabuses).

Syllabus is more specific than curriculum. Syllabus is an important tool in teaching and learning process. By using syllabus, teacher can manage the class effectively and the students can achieve the goal in learning process. Syllabus contents course content, procedures, and goals or learning objectives. Syllabus may organize according to a number of teaching and learning approaches. Nunan (1988:5) sates that "a syllabus is more localized and is based on the accounts and records of what actually happens at the classroom level as teachers and students apply a curriculum to their situation". The syllabus is an essential element in determining the teaching and learning quality. It is a great tool in teaching so the students know what will be taught in the class. The sets content of syllabus is graded and sequenced where the syllabus presents the goals, the teaching materials, and the teaching techniques recommended. The goals of a good syllabus are important to describe complete information about the target group and help the learners learn. While in language program, the syllabus identifies two sorts of goals: content goals and attitude goals. Content goals are concerned with the elements of language while attitude goals relate to the atmosphere of the language classroom.

Teacher has an important role to design a good syllabus for teaching and learning process. The teacher provides a number of course in the syllabus which is designed based on the students' needs. The teacher also makes final decisions about classroom management from each step of teaching in the syllabus. Thus the syllabus is the main tools for teachers in teaching. According to Parkers and Harris (2002) mentions the important functions of syllabus includes serving as a contract, serving as a permanent, and serving as an aid to students learning. They also mentioned several information shows in syllabus. First, a learning- cantered syllabus will provide information about how to plan for the tasks and experiences of the semester, how to evaluate and monitor one's performance, and how to allocate time and resources to areas in which more learning is needed. Second, a learning-cantered syllabus will give guidance to students about the learning to be done in the course. Third, the syllabus might help students to identify whether or not they are prepared for the work the course involves, and if not, what they might do about it. Fourth, a syllabus might be used to provide pieces of context about the course content for students so that they are able to see where the course fits in with other courses they have taken or will take. Fifth, a syllabus might help to teach other, broader lessons. Finally, a syllabus can serve students as a model of professional thinking and writing. Based on the information, the good component of syllabus should contain the course title or theme, the learning materials, the learning activities, the character building, indicator of competencies, assessment, time allocation, and source.

To design a syllabus is to decide what gets taught and in what order. For this reason, there is a need to design appropriate syllabus type for facing the students' problems in acquiring the target language. Krahnke (1987:10-11) mentions six types of language teaching syllabus a structural syllabus, a notional syllabus, a situational syllabus, a skill based syllabus, a task based syllabus, and a content based syllabus.

A structural syllabus or formal syllabus is one in which the content of language teaching is a collection of the forms and structures, usually grammatical of the language being taught. A notional syllabus or functional syllabus is a collection of the functions that are performed when language is used. A situational syllabus is a collection of real or imaginary situations in which language occurs or is used. A skill based syllabus is a collection of specific abilities that may play a part in using language. A task based syllabus is a series of complex and purposeful tasks that the students want or need to perform with the language they are learning. Moreover, a content-based syllabus is the teaching of content or information in the language being learned with little or no direct or explicit effort to teach the language itself separately from the content being taught.

A syllabus is a useful to both students and teacher. Matejki and Kurke (1994 in Albers 2003:61) mentions four ways a syllabus can be used as a teaching tool:

1. Contact.

The atmosphere of litigation and accountability that increasingly constrains the education process has planned a new emphasize on the syllabus as an agreement between students and instructor.

2. Communication Device. 
The syllabus also communicates succinctly to readers the expectations and experiences integral to a given course.

3. Plan.

The selection and sequencing of topics in syllabus conveys to students what the professor finds important and in what order these topic will be addressed.

4. Cognitive Maps.

An effective syllabus can go beyond merely listing subject matter; it creates a thematic framework that assists students in organizing the component parts of a course into a conceptual whole.

In designing a syllabus, there are two important points should be put before go to the specific part of syllabus. These are Competency Standard and Basic Competency. Competency Standard is the qualification of students 'minimal ability which illustrates the mastery of knowledge for every subject. Basic competency is a sum of students' ability subject as the references for determining the indicator for competency in a subject. Both are essential in grouping the methodology, materials related, and kinds of examination toward the students. These items relate each other and describe the purpose of the course, the goal, the time allocation, and the teaching and learning activities.

The planning of series of activities in the syllabus should content of a lesson depends on their age, abilities and interests. The good planning will make the students comfortable in the class. The reason is the learners respond to language according to what it does or what they can do with it. The lesson plan as what the teacher plans to do for the day and unit plans are what the teacher wants to do over several lessons. The kinds of activities can be applied in the lesson plans where the activity has an obvious communicative value. Ridnouer (2006:168) states sometimes students respond more positively to a lesson plan than we could have hoped; other times, they reject it entirely. The challenge is to take both scenarios in stride. Analyze each lesson plan for its strengths and its weaknesses, but keep in mind that every group of students has its own chemistry. In the syllabus design, the syllabus planner should consider important process in designing syllabus. He or she should know a good syllabus tends to the principle of teaching and learning behind it. The principles which can be conducted in the syllabus development are firstly the syllabus should make students get a level of understanding and high competence in the target language. The target language is based around what students need to communicate and what do they want to say. The appropriate planning which is essential to develop toward the learners' problem in mastering the target language is a skill based syllabus. The second is the syllabus should provide the learners to use the target language in real life situation. In this case the teacher needs to expand the students' knowledge and improve their English skills.

The third principle is that the syllabus should help learners to develop confidence and materials should able to courage the students in learning activities. Here the materials in syllabus should stimulate interaction between students and student, student and teacher by a number of tasks which is provided in text book or journal. Then the students should be given a standard exercises and clear instruction so they can easy to do the task and get the target language. Dealing with developing learning material for specific purposes especially English for Tourism, Hutchinson and Waters (1989:3) states that ESP is based on designing courses to meet learners' needs. Hutchinson and Waters (1989:90-94) propose four approaches of course design process: a language-centered approach, a skillscentered approach, a learning-centered approach, and the post hoc approach.

The fourth principle is the syllabus should offer the students to take advantage of learning activities opportunities outside the classroom. Therefore, the syllabus should be flexible and develop learning skills and strategies for students. The students can use the learning materials in daily interaction with the others. The next is the syllabus should expose the students to various moral values. The last is the syllabus should be authentic. It means the syllabus provides authentic cultural information about the target language so the students are able to differentiate between English and Indonesian culture.

Regarding to Indonesia curriculum which emphasizes the students on a good character, the syllabus and teaching material should develop a character building to the lesson plan. It is important to integrate in education because the education is an effective process to develop character. Education in the school will be developed to strengthen the good character building which child has from the family. By educating the character building in education, believe to avoid bad character. The students will have opportunity to develop their potentials become optimal.

Syllabus provides basic information about course content, activities and assignment planned for the term. The syllabus establishes the teacher's expectation, and procedures for the course.

The sets content of syllabus is graded and sequenced where the syllabus presents the goals, the teaching materials, and the teaching techniques recommended. The goals of a good syllabus are important to describe complete information about the target group and help the learners learn. While in language program, the syllabus 
International Journal of Social Science (IJSS)

Vol.1 Issue.5 February 2022, pp: 627-636

ISSN: 2798-3463 (Printed) | 2798-4079 (Online)

DOI: https://doi.org/10.53625/ijss.v1i5.1305

identifies two sorts of goals: content goals and attitude goals. Content goals are concerned with the elements of language while attitude goals relate to the atmosphere of the language classroom.

The concept of syllabus development is determining the quality of language input and the language practices during the learning process in the classroom. It makes the learners able to learn the language effectively. Therefore, the syllabus should able to giving a room for students to enhance their skills in acquiring the target language.

A syllabus design should be based on analysis of learners' needs. Procedures are used to collect information about learners' needs are known as needs analysis. It makes sure that a course will be relevant and satisfying to the learners because the need analysis refers to the elements of requirements related to the goals, which emphasized questions on who, why, where, and when. It is important to know who the students are, and their characteristic backgrounds. Nation \& Macalister (2010) defines needs analysis is directed mainly at the goals and content of a course. It examines what the learners know and what they need to know. Nunan (1988) divides there are two types of needs analysis used by the language syllabus designers; learners' analysis and task analysis.

Research and Development (R\&D) is a concept of designing syllabus. It contains steps to design a product. The model of Research and Development (R\&D) is provided by Borg and Gall. Borg and Gall (2003:569) states:

educational $R \& D$ is an industry based development model in which thefindings of research are used to design new products and procedures, which then are systematically field tested, evaluated, and refined until they meet specified criteria of effectiveness, quality, or similar standard.

Research and development refers to one research design aimed at developing and validating educational process. The process involves identifying problems that need to be solved by educational products, like textbooks, syllabus, assessment instrument, and other educational product.

Borg and Gall provided tenth steps of the systems approach model of educational research and development. The process comprises of 10 steps, namely (1) Assessing needs to identify goal, (2) Conducting instructional analysis, (3) Analysing learners and context, (4) Writing performance objectives, (5) Developing assessment instruments. (6) Developing instructional strategy, (7) Developing and selecting instructional materials, (8) Designing and conducting the formative evaluation of instruction, (9) Revising, and (10) Designing and conducting summative evaluation.

By doing the steps of R\&D method to design a syllabus, the syllabus can be applied at school. Of course the process of designing a syllabus is comprehensive and rather long. It may take longer time. It needs to do the detail steps and need to see every aspect comprehensively but the researcher of master program can do some steps of R\&D. Borg and Gall (2003:572-573) states it is highly unlikely that a graduate students will be able to find the financial and personal support to complete a major $R \& D$ project. $R \& D$ for a thesis or dissertation project, the researcher can avoid expensive instructional media and just doing a few steps of the R\&D cycle.

Dealing with the importance of learning English, Indonesia as a developing country puts English as the first foreign language to be taught. As the compulsory subject, Indonesian government focuses on helping students to master English in all level education. It proves that awareness of the language mastery has prevailed among societies especially in the tourism scope because English in the field is very important. English is the primary language of global trade and commerce and tourism in many countries, most tourism authorities and other officials in contact with the public speak English to interact and engage with tourists.

Since English has become an international language, it has become increasingly necessary in tourism. Additionally, many provinces in Indonesia put tourism sector as the priority to develop where it is conducted by Department of Culture and Tourism of West Nusa Tenggara (NTB). Website Resmi Pemprov NTB (2013) notes the president of Indonesia 'Susilo Bambang Yudoyono' and the governor of NTB 'Zainul Majdi' have launched a program named Visit Lombok Sumbawa (VLS) on July 6th, 2009 which aims to invite the foreign and domestic people visited Lombok and Sumbawa to see and enjoy the tourism objects. The background of the implementation of the program was based on the survey of Venue Magazine 2012, which put NTB as the top five provinces in Indonesia as the tourism object destinations after Bali, Pulau Komodo, Yogyakarta, and Jakarta. The survey also reports NTB is in the third grade as the organizer of MICE tourism (Meeting, Incentive, Convention, and Exhibition) after Jakarta and Bali. It means NTB plays an important role in tourism sector. The program succeeded to invite a big number of tourists, for this reason, on April 24th, 2012 coordinating minister for economic affairs Hatta Rajasa awarding Travel Club Tourism Award to NTB based on the program. The program is believed to increase the income of NTB because the NTB's economic growth is still in behind among the Indonesian provinces. The variety of NTB's cultures and stunning object tourism make the government of NTB targeting one million of tourists visit to Lombok and Sumbawa. Therefore, Department of Industry, Trade, and Cooperatives of West Nusa Tenggara and NTB's governor cooperatively initiated the development of the program by facilitating the access to the tourist 
object, developing the promotion, and strengthening the management of tourism sector because they have responsibility to promote and empower the potential in tourism.

The development of tourism sector in NTB and English language are two important things, which are not able to be separated one another where English is needed to convey all information dealing with tourism. The English language also influences the success of the tourism program. Consequently, all stakeholders should take part to support the program especially school. School is able to facilitate students acquiring the target language by giving special attention to English. The school does not only provide students with English as the compulsory course, but also give a time for English for specific purposes (ESP) to be taught. The English for specific purposes is different from General English. Holme (1996 in Basturkmen 2010:2) states the General English syllabus is based on a conception of the kind of reality that the student has to deal with in English. ESP is simply a narrowing of this needs spectrum. The ESP process of specialization should not result in the complete separation of one part of the language from another.

One of ESP courses can be implemented in school is English for tourism. The teaching of English for tourism course is expected to able to develop English skills for students, consequently, the students at the end of their education in senior high school will have adequate skill and expertise in tourism. The course is essential tool in teaching any various issues concerning tourism industry, such as a travel agent, offering destination guides to the tourists, writing and sending email and faxes, hotel booking, making on line ticketing, and guiding the tourist. In addition, learners who seek employment in the tourism and service industry need high motivated to be truly fluent in English for tourism. Various factors must be considered by educators in designing this course, which will benefit students, increase motivation and improve language skills.

English for Tourism is one of the most attractive because it emphasizes the development of English skills for students. For instance, by promoting reading skills, the students are expected to work in business administration, or in speaking skill, the students are expected to be tourist guides. More importantly for English for tourism course which major in tourism must be relevant with the students. The special term and language use in tourism has to be introduced to students so that they will have good communicative competence. Conscious of the importance of English for Tourism course, SMKN 1 Praya, where the researcher conducted the research provides the course. The course is just an extra course where it put as muatan lokal or local content.

In preliminary observation, the researcher found that the course does not have a syllabus. As a result, every semester the teacher teaches different materials to the students. In teaching the materials, the teachers focus on giving speaking materials where it takes from internet and English for tourism textbooks for general and for scoring the teacher gives speaking test.

Very often the materials which are taken from internet and ready made English for tourism textbook have problems on contents and do not provide an appropriate assessment and testing for students. The materials were lack of relevance with the students because the materials do not cover the goal of both Curriculum KTSP and Curriculum 2013 where the feature of curriculum KTSP focuses on exploration, elaboration, and confirmation, and Curriculum 2013 includes observing, questioning, exploring, associating, and communicating. Therefore, for solving those problems, this study was administered where there is urgent need to design syllabus, which are fulfil what the English learners need.

Based on the identification of problems, the urgent problems at the SMKN 1 Praya were as follows;

1. The students need to learn a specific skill for English for tourism. As a result, the students able to cater the course.

2. The fact that the English for Tourism at SMKN 1 Praya as extra course, as a result, the school does not provide the syllabus.

3. There is no English syllabus for English for Tourism makes the teacher just pick the materials from internet and apply them at classroom.

4. English for Tourism textbook for SMA doesnot available in the market.

5. Due to the materials are taken from internet and English for tourism textbooks for general, the content of materials do not cover the goals of curriculum.

6. The teacher uses free technique to conduct the class because there is no role obligationin written form relate to the materials.

This research focused on designing English syllabus for tourism at the eleventh grade of SMKN 1 Praya by applying the features in curriculum 2013. Before designing the syllabus, there were an investigation to know the needs of students and teacher.

The objectives of this research are:

1. To know the English skill needs to be learned by the students of English for tourism for the eleventh grade of SMKN 1 Praya 
International Journal of Social Science (IJSS)

Vol.1 Issue.5 February 2022, pp: 627-636

ISSN: 2798-3463 (Printed) | 2798-4079 (Online)

DOI: https://doi.org/10.53625/ijss.v1i5.1305

2. To determine the suitable English syllabus for tourism at the eleventh grade students of SMKN 1 Praya by measuring the effectiveness of the syllabus developed

\section{METHODS}

The main objective of this research was to design English syllabus of English for tourism for the eleventh year student at SMKN 1 Praya. This research was qualitative method and it was developed by Research and Development (R\&D).

The target population in needs analysis refers to the people about whom information will be collected. In this study the populations were taken from the SMKN 1Praya students. Those students are Sasak therefore in their daily conversation, they use their mother tongue. Hence, Sasak is their native language. They only use Indonesian at school.

The number of population is 260 students of the eleventh grade students. Their age range was found to be 16-19 years of age. The sample was taken by systematic random sample. It was taken randomly without considering other factors, such as family's background, parent's education level, and students' genders. They were chosen by lottery technique.

The research was 10 percent from the whole population as sample. Sukmadinata (2013:263) states that "besarnya sample diambil $10 \%$ dari seluruh populasi..." Therefore the sample was 26 students and two English teachers of SMKN 1 Praya.

In term of English teachers as the samples, they have been teaching at the school at least eight years so that they have enough knowledge and experience in teaching and learning process.

This research was designed by adopting five cycles in Research and development (R\&D). They were (1) needs analysis (2) draft development (drafting) (3) field test, (4) revision (5) final production. The needs analysis was done by analysing the students and teachers needs. Based on the needs, the draft of syllabus was design. The design included teaching material and lesson plan. After developing the preliminary form of the product, the next step was field test. It was to know the quality of the syllabus. Then, the revision was done based on the feedback from the teachers.

Techniques of data collecting used in this study were observation, questionnaire, interview and documentary study.

In terms of questionnaire, the writer was used a questionnaire as an instrument to collect the data. It covered content and method of designing syllabus of English for tourism. The questionnaire was addressed to the students and teachers. Before filling the questionnaire sheet, the researcher explained about the purpose of the research to the students and teachers.

In terms of interview, it was conducted in case there was some important information which could not be gained in the questionnaire. This interview was held in the break time.

In terms of documentary study, this technique was conducted in case to drive some important information from document. The writer was collected document which dealing with Curriculum 2013.

In the field test of the syllabus, observation was done to know the effective of the syllabus. The observation was done by taking some notes overall activities and processes of teaching learning. The English teacher wrote the teaching and learning process on the observation sheet.

The writer was analysed the data through the following steps;

1. Firstly, the writer analysed the needs basedon the questionnaire given to students and teachers and interview to them.

2. Secondly, based on the data analysis in no. 1, the writer found out a specific skill for English for tourism course and material would be designed.

3. Thirdly, in order to see how effective the syllabus, the writer tried out the syllabus. There were five meetings implemented in restricted class and the whole class.

4. Fourthly, after doing the implementation, the researcher gave speaking test to students. The test was to know the effectiveteaching materials.

5. The last, the researcher also gave post trial sheet to students and teacher. The comments was become the researcher's consideration in revising the syllabus.

In terms of time, the research was conducted from March to April 2021. 


\section{RESULTS AND DISCUSSION}

The syllabus determines what kind of materials will be adopted and in what ways they will be exploited for the classroom teaching. Parker and Harris (2002:55) stated the syllabus as a contract, the syllabus as a permanent record, and the syllabus as a learning tool. Each function has implications for what a syllabus should contain.

The final product of this study was syllabus of English for tourism, which designed, based on scientific approach in syllabus of Curriculum 2013. By understanding those scientific approaches and know how to apply it in the classroom, the teachers can play their roles during teaching and learning process because Curriculum 2013 is based on process oriented, not product oriented. This is important because the syllabus can create the student's competency to communicate in the target language. In Curriculum 2013, every subject supports all competencies (attitude, skill and knowledge) where the subject is designed based on basic competence and core competence.

Designing is a process of creating syllabus based on the needs gathered on the needs analysis. The designing of EFT syllabus for SMKN 1 Praya students was derived from the needs of teacher and students. For EFT learning material, the drafting of the material in the syllabus based on the speaking skill. The speaking skill was chosen because $80.27 \%$ respondents need speaking skill to be learned. Therefore the answer for the first research question, English skill needed to be learned by the students of English for tourism for the eleventh grade of SMKN 1 Praya, was speaking skill.

The majority of informants answered that they want to be able to speak English fluently because they feel it would be useful in pursuing other interests or career goals. Due to the students need speaking skill in learning English for tourism so that the kind of syllabus was skill based syllabus. The skill based syllabus emphasize on specific English skill to be learned.

The goal of teaching speaking skills is communicative efficiency. Learners should be able to observe the social and cultural rules that apply in each communication situation. In designing the EFT syllabus, which is based on speaking skill, need teaching materials and technique for oral practice in the classroom. Ommagio (1986 in Stein 1999) states, "Oral proficiency includes the ability to communicate verbally in a functional and accurate way in the target language. A high degree of oral proficiency implies having the ability to apply the linguistic knowledge to new contexts (topics) and situations." Considering the goals of teaching speaking skill, the researcher was selecting language functions as the learning materials. The language functions were applied as the teaching material in this syllabus based on the context of tourism object. At the first semester the informants wanted to study about describing, asking for and offering help, agree and disagree, asking for and showing direction, likes and dislikes, giving instruction and giving advice. At the second semester the informants wanted to study about making and cancelling appointment, greeting, showing traffic sign, expression capabilities, expression inviting, expression impression and appreciation, expression offering things and service and offering choice. In term of selecting topic of English for tourism course, the researcher determined two types of topics; topic of local object and topic of tourism object. First, topic of local objects that shows the Lombok feature is bau nyale festival, senggigi beach, Sade village, gendang beleq and nyongkolan. Second, the topic of tourism object, which shows tourism, is restaurant, hotel, and airplane/transportation holiday and art shop. The cultural notes also involved in teaching materials where it aims to make the students understand about the cultural aspect in communication. Therefore, from the needs analysis, it can be summarized into need profile of lack, wants and necessities. In term of lack, the students' English proficiency is low and thinking that learning English is difficult. In term of needs, the students need to learn speaking by practical method. In term of wants, the students want to learn language functions. Therefore there were four point could be collected in the needs analysis namely learners' language needs, learners' learning needs, learners' objective needs and learners' subjective needs. The language needs was referred to designing EFT syllabus for the eleventh grade students. The learners' learning needs was referred to the students were needed active learning and group discussion. The objective needs were referred to the lesson. It was language use and two themes of materials provided namely topic of tourism object and local object. In addition, the subjective needs were referred to the students wanted to learn speaking. All the information was needed to determine the content of the EFT syllabus.

After collecting the needs of EFT syllabus, the researcher drafted the syllabus. The next step was implementation. The field test or implementation was done two times. It was done to know the quality of the syllabus. Sukmadinata (2013:185) there were two steps of implementation namely restricted field test and whole field test.

In the implementation, the teaching technique was emphasized on group work. By group work, the students are easily to talk and share their mind to the others. Harmer (2007:166) states that group work dramatically increases the number of talking opportunities for individual students. Based on the result, the students had significance score from the first to the third trial. It indicated that the teaching material was effective. The final project was developed through modification and revision based on the English teachers, students and vice principals feedback. The final 
International Journal of Social Science (IJSS)

Vol.1 Issue.5 February 2022, pp: 627-636

ISSN: 2798-3463 (Printed) | 2798-4079 (Online)

DOI: https://doi.org/10.53625/ijss.v1i5.1305

version of EFT syllabus consisted of core competency, basic competency, learning materials, learning activities, assessment, time allocation, and source. In term of core competency, there are three indicators need to be achieved by the students.

In term of basic competency, the teaching and learning process focus on analyzing, understanding the social function of spoken text and creating the spoken text. The process emphasizes on communicative activities where the students have a chance to practice their knowledge of each spoken topic given. The activities applied were conversation, role play, picture based speaking and discussion. The syllabus also provides evaluations, which were taken from learners' active participations and performances during the lessons. The syllabus of English for tourism is suitable to be applied for teacher in teaching EFT in the classroom. Therefore the answer for the second research question, the appropriate design of the EFT syllabus for SMKN 1 Praya students, was the syllabus which meets the need of school syllabus, teacher and students, be inserted with scientific approach.

\section{CONCLUSION}

The skill need in learning English for tourism at SMKN 1 Praya is speaking. From the result of questionnaire and interview, the majority of students need speaking skill therefore the kind of EFT syllabus for SMKN 1 Praya is skill based syllabus because it emphasizes on specific skill.

The EFT syllabus for SMKN 1 Praya was designed by using R\&D method. In the theoretical part the researcher introduced the theoretical background concerning designing ESP and mentioned some characteristic features closely connected with process of designing ESP syllabus. Before designing the syllabus, the researcher conducted needs analysis by interviewing 27 respondents and giving questionnaire to them. The information obtained from the interview and questionnaires were used as the basis to design the syllabus. Topic, theme and the content in the syllabus were mainly very close to students' daily life because the materials about language functions. It was presented in a simple way and interesting to students so that the students could understand the materials more easily. The syllabus is designed by following the format of syllabus Curriculum 2013 where it emphasizes on scientific approach. After the syllabus was completely designed, the researcher conducted try out in five meetings for restricted class and the whole class. Then, the researcher evaluated the syllabus by giving test to students in the classes, questionnaire to know their opinion, and questionnaire to teachers about their feedback of the syllabus. From the implementation were resulted significance differences between the first, the second and the third trial. The average score for the first was 4.00 , the second was 4.32 and the third trial was 4.80 . It indicates that the quality of the syllabus is good.

\section{SUGGESTION}

The researcher provides suggestions for teacher and other researchers who want to conduct similar study.

1. Teachers and headmaster may implement this model as an alternative for teaching and learning process because the format of this syllabus is based on Curriculum 2013.

2. In conducting needs analysis, other researchers should make questionnaire clearly to the respondents.

\section{ACKNOWLEDGEMENTS}

In the name of Allah the most gracious and the most merciful. All praises be to the Almighty Allah who has bestowed me courage and spirit to make this work properly finished. Peace and salutation is going to His special massager and servant, Prophet Muhammad SAW (peace be upon him), who has brought us from the darkness to the lightness.

This work is originally a thesis for my Master degree in Mataram University under the supervision of Prof. Drs. Nurachman Hanafi, M.A, Ph.D., and Dr. Muhammad Amin, M.TESOL. To them my deepest appreciation is due. Thank you for your guidance, constructive suggestions and advices since my script process, without you this thesis cannot be completed.

My deepest appreciation is devoted to my beloved parents, sister, brother in law and my little niece. They have been supporting and leading me to a brighter life. I acknowledge that I would be nothing without them.

Finally, my warmest gratitude also goes to all people and friends who helped me in writing this thesis. Hopefully, the study will be beneficial not only for SMKN 1 Praya but also for other researchers who plan to do the same research in the future. 


\section{REFERENCE}

[1] Basturkmen, Helen. 2010. Developing Course in English for Specific Purposes. New Zealand: University of Auckland.

[2] Bowen, J. Donald., and Madsen, Harold., and Hilferty, Ann. 1985. TESOL: Techniques and Procedures. Cambridge: Newbury House Publisher.

[3] Gall. Meredith D. \& Gall. Joyce P. 2003. Educational Research. New Jersey: Pearson Education, inc.

[4] Harmer, Jeremy. 2007. The practice of English Language Teaching fourth Edition. England:Pearson Education.

[5] Krahnke, Karl J. 1987. Approaches to Syllabus Design for Foreign Language Teaching. New Jersey: PrenticeHall.

[6] Nation, I.S.P. \& Macalister, John. 2010. Language Curriculum Design. New York: Routledge.

[7] Nunan, D. 1988. Syllabus Design. Oxford: Oxford University Press.

[8] Parkes, Jay., and Harris, Mary. 2002. The Purpose of Syllabus vol. 50/no. 2. University of New Mexico. EBSCO Publishing.

[9] Richard, Jack C. 1990. The Language Teaching Matrix. Cambridge: Cambridge University Press.

[10] Richards, Jack C., and Lockhart, Charles. 2001. Curriculum Development in Language Teaching. Cambridge: Cambridge University Press.

[11]Richards, Jack C., and Lockhart, Charles. 2013. Curriculum Approaches in Language Teaching : Forward, Central, and Backwash Design. Australia: University of Sydney.

[12] Simion, Mindora Otilia. 2012. The Importance of Teaching English in The Field of Tourism in Universities: Economy Series, Issue 2/2012. Romania: University of Târgu-Jiu.

[13] Stein, Miriam. 1999. Developing Oral Proficiency in the Immersion Classroom. ACIE Newsletter . Volume 2 Number 3 May 1999.

[14] Sukmadinata, Nana Syaodih. 2012. Metode Penelitian Pendidikan. Jakarta: Remaja Rosdakarya.

[15] Tomlinson, Brian. 1998. Materials Development in Language Teaching. Cambridge: Cambridge University Press.

[16] Website Resmi Pemprov. NTB. 2013. Lombok Destinasi Terfavorit Kelima Nomor Tiga untk Wisata MICE.

[17] Website Resmi Pemprov. NTB. (2013). NTB Raih Penghargaan Pariwisata. http://www.ntbprov.go.id/baca.php?beri ta=1179. Accessed on January 23rd, 2014 at $11.21 \mathrm{pm}$. 